\title{
FIRST RECORD OF THE BLUE-WINGED WARBLER IN MANITOBA
}

KEITH A. HOBSON, Department of Zoology, University of Manitoba, Winnipeg, Manitoba. R3T 2N2

At $1015 \mathrm{~h}$ on 7 November 1987, while the author was censusing birds along the dune-ridge forest at the University of Manitoba Field Station (Delta Marsh), Manitoba, a male Blue-winged Warbler was observed. ${ }^{3} 4$ The bird was foraging in a mixed-species flock of three Blackcapped Chickadees, two Ruby-crowned Kinglets and a Downy Woodpecker. Visibility was excellent and the ambient temperature was $-1^{\circ} \mathrm{C}$ at $1000 \mathrm{~h}$.

The first glimpse was of the bird's bright yellow plumage which contrasted dramatically with its black lores. Closer observation using $8 \times 32$ binoculars at 3-5 $\mathrm{m}$, revealed the following characteristics: the golden-yellow forehead became olivetinged on the crown; the nape, mantle and rump were olive-green, and the upper tail and wings were grey; two whitish wing bars were distinct; throat, cheeks and underparts were a uniform bright yellow except for a whitish crissum; the bill was thin and black and there was a narrow black eyeline extending to the base of the bill. Occasionally the bird fanned its tail, revealing two white under-tail spots near the tip.

The bird foraged for about 5 minutes on and near the ground amongst dense shrubs, dead burdock and nettles. It moved rapidly and frequently changed locations with short $(5-10 \mathrm{~m})$ flights. The bird was seen again at $1155 \mathrm{~h}$ about 80 $\mathrm{m}$ from its original location. It was still with two Black-capped Chickadees and was viewed within $3 \mathrm{~m}$ for about 5 minutes. It was located again with the chickadees at $1230 \mathrm{~h}$ when it was observed drinking from shallow water in a ditch. Photos were taken and are filed at the Manitoba Museum of Man and Nature, Winnipeg. This warbler was last seen on that day at $1700 \mathrm{~h}$ foraging about $40 \mathrm{~m}$ from where it was first located. No other birds were seen nearby.

The Blue-winged Warbler was observed the next day about $100 \mathrm{~m}$ from its original location by Rudolph Koes and family,

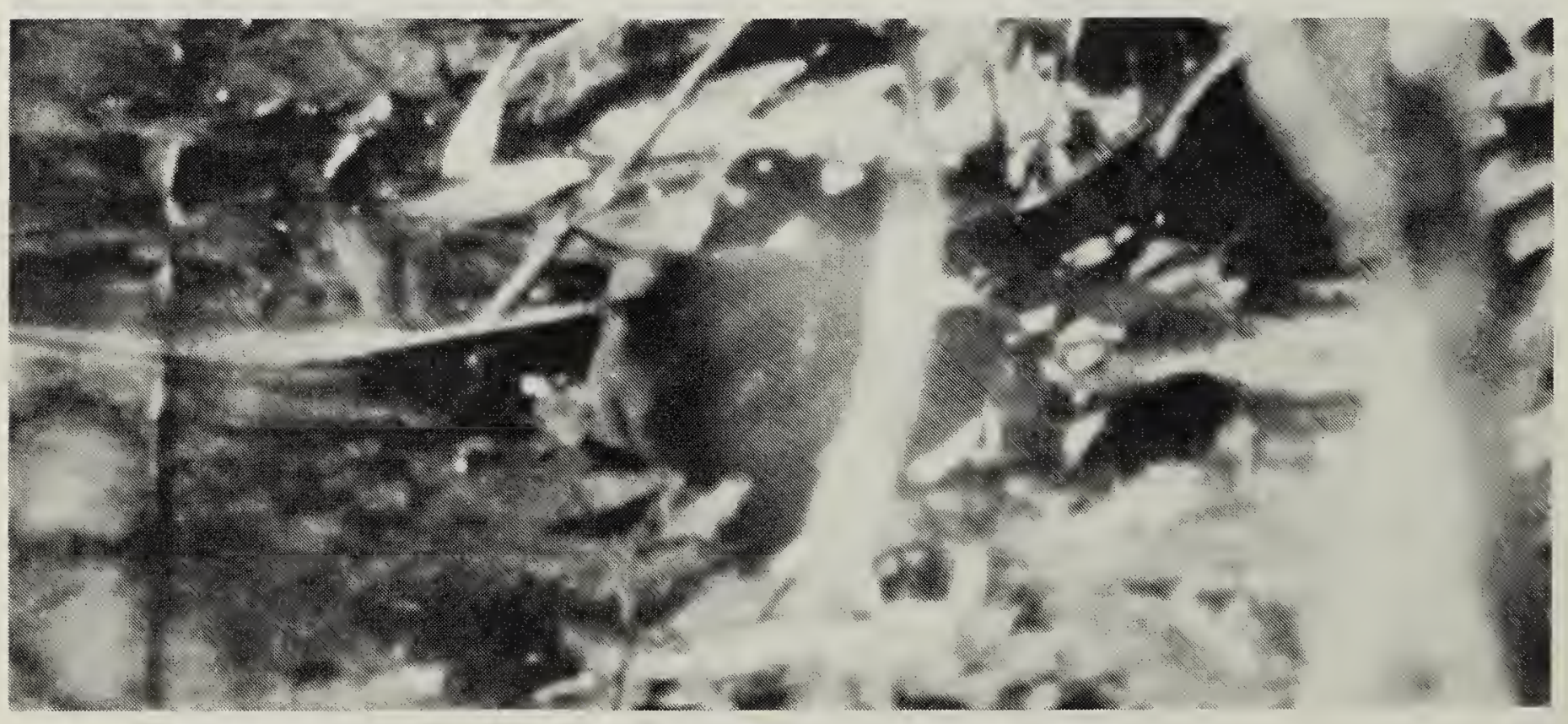


Robert Parsons, George Holland, Norm Cleveland and Russel Tkachuck. Based on his field notes, $R$. Koes believed the bird was a first-winter male (R. Koes, in litt.).

Although C.L. Broley recorded a female of the "Brewster's Warbler" (hybrid of the Golden-winged and Blue-winged warblers) east of Winnipeg in 1932, this sighting is the first Manitoba record for the Blue-winged Warbler. ${ }^{2}$ It is likely that, after leaving breeding grounds to the south, the bird became disoriented and migrated north instead of south to its regular wintering grounds. The closest breeding population occurs in southeast Minnesota.' On 6 November, the day before the observation, winds were from the south at 8-16 $\mathrm{kmph}$ and the temperature reached $5^{\circ} \mathrm{C}$. These conditions may have favoured a northward movement. Brazier similarly explained Saskatchewan's first specimen record of this species, a first-winter male obtained 9 November 1965.'

\section{Acknowledgements}

I thank Herb Copland and Rudolph Koes for helpful information and assistance. Mike Bryan provided technical assistance and Spencer G. Sealy provided helpful comments on an earlier draft of this manuscript. This is publication No. 44 of the University of Manitoba Field Station (Delta Marsh).

' BRAZIER, F. 1966. Saskatchewan's first specimen of the Blue-winged Warbler. Blue Jay 24(1):9-10.

2 LAWRENCE, A.G. 1932. Chickadee Notes, Column 584. Winnipeg Free Press. June 03.

3 MACKENZIE, D.I. 1982. The dune-ridge forest, Delta Marsh, Manitoba: overstory vegetation and soil patterns. Can. Field-Nat. 96:61-68.

4 SEALY, S.G. 1980. Breeding biology of Orchard Orioles in a new population in Manitoba. Can. Field-Nat. 94:154-158.

\section{BALD EAGLE KILLS AND CARRIES GIANT CANADA GOOSE}

JOHN BARTLEY, Rennie, Manitoba. ROE 1RO

An article in the March 1987 Blue Jay about Bald Eagles preying on waterfowl has prompted me to record the following brief observation. Canada Geese nesting at the Alf Hole Goose Sanctuary in the Whiteshell Provincial Park near Rennie, Manitoba, have been identified as Giant Canada Geese, a subspecies weighing from 9 to 20 pounds. At Rennie, they arrive back in late March when open water may be limited. On 30 March 1988, while patrolling my trapline along the Whiteshell River near Mallard Lake the author flushed a flock of 15 geese from open water near a beaver dam. As they rose from the water an adult Bald Eagle suddenly dropped down from the sky and struck one. The goose fell to the ice and was quickly picked up by the eagle. The eagle flew off low with the goose, carrying it roughly 70 feet away to the far shore of the river where it dropped out of sight.

Later that day, at Basket Falls, another adult Bald Eagle was flushed from its resting place in a tree by the noise from my power toboggan. As it flew off, a large flock of Canada Geese swimming on the open water below the falls became extremely nervous; several of them dove beneath the surface of the water. This suggests that the geese recognised the eagle as a threat. 